\title{
Plasma zinc and hair zinc levels, anthropometric status and food intake of children in a rural area of Brazil ${ }^{1}$
}

\author{
Zinco plasmático e zinco capilar, antropometria \\ e consumo alimentar de crianças em uma \\ região rural do Brasil
}

Mark Anthony BEINNER²

Maria Ângela de Barros Correia MENEZES ${ }^{3}$

Jose Bento Borba da SILVA4

Flavia Regina de AMORIM4

Ann Kristine JANSEN ${ }^{2}$

Joel Alves LAMOUNIER ${ }^{5}$

A B S T R A C T

\section{Objective}

The objective of this study was to investigate the levels of plasma zinc, hair zinc, growth and food consumption in children aged 6 to 24 months in a rural area of Diamantina (MG), Brazil.

\section{Methods}

Plasma and hair zinc concentrations were analyzed using flame atomic absorption spectrometry and neutron activation analysis, respectively. Weight-for-age, weight-for-height and height-for-age, expressed as Z-scores, were measured according to the World Health Organization reference curves. Dietary zinc intake was determined by a 3-day dietary recall filled out by the mother or guardian.

\section{Results}

Zinc deficiency was found in $11.2 \%$ and $16.8 \%$ of the children according to plasma zinc e hair zinc levels, respectively. Mean plasma zinc and hair zinc for children $\leq 11$ (49) and >11 (127) months of age were 15.4

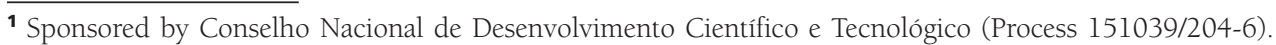

2 Universidade Federal de Minas Gerais, Escola de Enfermagem, Departamento de Enfermagem. Av. Alfredo Balena, 190, $4^{\circ}$ andar, Sala 422, 30130-100, Belo Horizonte, MG, Brazil. Correspondência para/Correspondence to: M.A. Beirnner. E-mail: <mbinner@yahoo.com.br>

3 Centro de Desenvolvimento da Tecnologia Nuclear, Comissão Nacional de Energia Nuclear, Divisão de Reatores e Irradiação, Laboratório de Análise por Ativação com Nêutrons. Belo Horizonte, MG, Brazil.

${ }^{4}$ Universidade Federal de Minas Gerais, Instituto de Ciências Exatas, Departamento de Química. Belo Horizonte, MG, Brasil.

${ }^{5}$ Universidade Federal de Minas Gerais, Escola de Enfermagem e Nutrição, Departamento de Pediatria. Belo Horizonte, MG, Brasil. 
$(\mathrm{SD}=4.2) \mu \mathrm{mol} \mathrm{L} \mathrm{L}^{-1}$ and $139.5(\mathrm{SD}=72.1) \mu \mathrm{g} \mathrm{g} \mathrm{g}^{-1}$ and $16.0(\mathrm{SD}=4.5) \mu \mathrm{mol} \mathrm{L}^{-1}$ and $134.3(\mathrm{SD}=110.3) \mu \mathrm{g} \mathrm{g}^{-1}$, respectively. Anthropometric measurements showed that $8.0 \%, 6.8 \%$ and $3.4 \%$ of the children were underweight, stunted and wasted, respectively. The mean dietary intake of zinc was 3.2 (SD=2.3) mg/day. One-third of the children did not eat enough foods that contain zinc. There were no correlations among plasma zinc level, hair zinc level, anthropometric parameters and zinc intake.

\section{Conclusion}

The results demonstrate that zinc deficiency is a problem in the studied population, not just in malnourished children. Nutritional care should be provided for this population in order to improve their consumption of high-zinc foods and monitor zinc deficiency.

Indexing terms: Anthropometry. Blood. Child. Hair zinc. Nutritional status. Zinc.

\section{RE S U M O}

\section{Objetivo}

Investigar níveis plasmáticos de zinco, concentração de zinco capilar, crescimento físico, e consumo de zinco em crianças de 6 a 24 meses da região de Diamantina (MG), Brasil.

\section{Métodos}

As concentrações de zinco plasmático e zinco capilar foram analisadas empregando as técnicas de espectrometria atômica de absorção e de ativação neutrônica, respectivamente. Peso-para-idade, peso-paraaltura e altura-para-idade, expressos em escore-Z, foram medidos, de acordo as curvas de referência da Organização Mundial de Saúde. O zinco dietético dos sujeitos foi avaliado a partir de três registros alimentares, preenchidos pelas mães ou responsáveis.

\section{Resultados}

A deficiência de zinco foi observada em 11,2\% e em 16,8\% das crianças, segundo os níveis de zinco plasmático e zinco capilar, respectivamente. As médias em crianças com 11 meses ou menos (49) e 11 (127) meses ou mais de idade para níveis de zinco plasmático e zinco em cabelos foram 15,4 (DP=4,2) $\mu \mathrm{mol} \mathrm{L}^{-1}$ e $139,5(D P=72,1)$ $\mu g g^{-1}$ e $16,0(D P=4,5) \mu m o l ~ L^{-1}$ e 134,3 $(D P=110,3) \mu g g^{-1}$, respectivamente. Os resultados antropométricos mostraram que $8,0 \%, 6,8 \%$ e 3,4\% das crianças foram classificadas com baixo peso, baixa estatura e emagrecidas, respectivamente. A média do consumo dietético de zinco pelas crianças foi de 3,2 (DP=2,3) mg/zinco por dia, e um terço das crianças consumiam alimentos fonte de zinco abaixo do recomendado. Não houve correlação entre as variáveis zinco plasmático, zinco em cabelos, antropometria e consumo de zinco.

\section{Conclusão}

Os resultados demonstram que a deficiência de zinco é um problema na população estudada, não somente nas crianças desnutridas. Atenção nutricional deverá ser direcionada a esta população, com o intuito de melhorar o consumo de alimentos ricos neste mineral e monitorar a deficiência de zinco.

Termos de indexação: Antropometria. Sangue. Criança. Zinco capilar. Estado nutricional. Zinco.

\section{NTRODUCTION}

As a developing country, Brazil has undergone substantial improvements over the last several decades regarding the socioeconomic status of its inhabitants. As a result, the epidemiological transition has changed; to a lesser extent, micronutrient deficiencies, acute diarrhea and low birth weight have decreased over the last two and a half decades. However, isolated nutrient deficiencies continue to plague Brazil, such as iron
$(\mathrm{Fe})$ and vitamin A deficiencies, which affect mainly poor children and childbearing women'.

A zinc deficiency largely results from inadequate consumption of high-zinc animal source foods and is seen in many underdeveloped countries. The typical diet in these countries consists mainly of grains and legumes, which contain inhibitors of iron and zinc absorption ${ }^{2}$. A serious consequence of low zinc intake, particularly in young children, is diarrhea, which 
causes an excessive loss of this mineral through the feces. Zinc is an essential nutrient and plays an important role in several aspects of cellular metabolism. It is critical for normal immune function as well as body growth ${ }^{3}$.

In Brazil, data on zinc deficiency are scarce; however, some published studies have shown low levels of plasma zinc and hair zinc in at-risk populations, principally children ${ }^{4,5}$.

The aim of this study was to investigate plasma zinc and hair zinc levels, dietary zinc intake and growth by taking the anthropometric measurements of poor children in the northeastern region of Minas Gerais, Brazil.

\section{METHODS}

The study was conducted in the rural districts of the small historic town of Diamantina (population 44,259) located in the Upper Jequitinhonha Valley in the State of Minas Gerais, Brazil. The area is inhabited by individuals of low socioeconomic status and has poor hygiene conditions. The main economic activity is subsistence farming, but the main occupation in this semi-arid region is diamond and gold mining. The staple foods include rice, beans, pasta, corn, manioc root, and in lesser amounts, chicken, pork and beef. Free-range livestock farming is not common in this region due to the harsh, dry, seasonal conditions, which last from May to October. Gold and diamond mining is the main occupation of $85 \%$ of the studied households, and their estimated median monthly household income

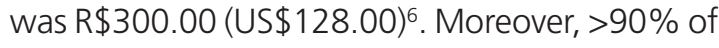
those identified as head of the household or primary caregiver had only elementary school education.

The population consisted of children aged 6 to 24 months living in the 8 rural districts around Diamantina. According to the Brazilian Census of the year $2000^{6}, 312$ children aged 6 months to 2 years were registered in the following eight rural districts of Diamantina: São João da Chapada - 45; Sopa - 7; Conselheiro Mata - 32; Desem- bargador Otoni - 87; Planalto de Minas - 24; Senador Mourão - 39; Mendanha - 17; and Inhai - 61. Based on this Census, invitation letters and consent forms were hand delivered by community health workers to the parents of children enrolled in any one of the health outposts. Most children were apparently healthy (presenting no obvious or reported medical problems). The parents needed to show the child's vaccination and weight control card containing birth weight information for inclusion in the study. All children whose parents consented had their baseline data measured between August and December 2006. A questionnaire administered to the mothers by trained nurses was used to collect socioeconomic data (mother's education level, monthly income and living conditions) before the assessment began. A total of 99 mothers or guardians agreed to fill out the questionnaire. The research protocol was approved by the Human Ethics Committee of Universidade Federal de Minas Gerais (UFMG) (Process number 238/06).

\section{Experimental procedures}

\section{Anthropometric measurements}

Anthropometric measurements (weight and height) were taken by four individuals following the World Health Organization (WHO) recommendations ${ }^{7}$. Infants were weighed naked (to the nearest $100 \mathrm{~g}$ ) on a digital infant scale (Seca Inc., Sydney, Australia). Recumbent length was measured to the nearest $0.1 \mathrm{~cm}$ with an infant tape measure (Unicef, Brazil). Z-scores were calculated for three of the anthropometric measurements using the Epi Info software (Centers for Disease Control, Atlanta, USA). Stunting, wasting and underweight were defined, respectively, as lengthfor-age, weight-for-length and weight-for-age $<-2$ Z-scores ${ }^{8}$.

\section{Dietary assessment}

Twenty-four-hour dietary recalls were administered three times (Tuesday, Thursday and 
Saturday) to 96 of the 99 mothers or guardians who answered the questionnaire and consented to the dietary assessment. The mother or guardian was instructed to write down the foods consumed by their child during a 24-hour period over the three nonconsecutive days. Illiterate mothers or guardians were visited in their homes by nutritionists and instructed to recall the foods consumed by their children. Nutrition students were trained to use a quantitative and qualitative 1-day dietary recall sheet to track the foods and beverages that the mothers or guardians fed their children during the recall period. Photographs of foods and utensils were used to assist mothers in recalling types and quantities of foods and beverages during the interview. Interviewers also followed a standardized interview format and were trained to probe for details about the foods and beverages that were consumed, such as the brand name, amounts, ingredients, and cooking method. The zinc content of foods was determined using a Brazilian food composition table as well as a complementary food composition table ${ }^{9,10}$. To obtain a distribution of usual intakes for a group, the distribution of observed intakes (i.e., the intake obtained from a single 24-hour recall) was statistically adjusted to cancel the effects of withinperson variability, so that the distribution reflected only between-person variability according to the Dietary Reference Intakes (DRI) ${ }^{11}$. Once the individual intake values were adjusted, the prevalence of inadequate intake was calculated comparing the Estimated Average Requirement (EAR), according to the DRI reference values ${ }^{11}$.

\section{Blood sampling and analysis}

Heparinized venous blood samples ( $3 \mathrm{~mL}$ ) were collected at the local health outpost for biochemical assessment of plasma zinc. Heparin venous blood vacuum collection tubes (Greiner Bio-one, USA) were used to avoid zinc contamination. All blood samples were stored at $4^{\circ} \mathrm{C}$ to prevent hemolysis and centrifuged within 4 hours. Plasma aliquots were stored at $-80^{\circ} \mathrm{C}$ until analyzes. At the laboratory of Oswaldo Cruz, in Diamantina, C-reactive protein (CRP) was measured as an indicator of infection using nephelometry (Turbox; Orion Diagnostica, Finland) with control material provided by the manufacturer. Plasma zinc concentrations were analyzed at the Department of Chemistry of the Universidade Federal de Minas Gerais, using an Analyst 300 flame atomic absorption spectrometer according to the manufacturer's instructions (Perkin Elmer, Norwalk, CT, USA). The plasma was diluted with deionized water 1 plus $4(500 \mu \mathrm{L}$ of plasma and $2 \mathrm{~mL}$ of water). Zinc deficiency ${ }^{12}$ was defined as plasma zinc $<10.7 \mu \mathrm{mol} \mathrm{L}^{-1}$. CRP ${ }^{13}$ was considered high if its concentration were $>10 \mathrm{mgL}^{-1}$.

\section{Hair sampling and analysis}

Proximal $3 \mathrm{~cm}$ of hair samples were cut with stainless steel scissors from the occipitonuchal region of the head, adjacent to the scalp. All samples were stored in zinc-free, polypropylene containers until analysis. Samples were washed ${ }^{14}$ following the International Atomic Energy Agency (IAEA) recommendations, that consists of washing each sample in a clean beaker with mechanical agitation and $25 \mathrm{~mL}$ portions of, successively, water, acetone, water, water, acetone, water, decanting the wash liquid after a 10-minute wash. This procedure is published in an IAEA report, IAEA RL/50, 1978, by Y.S. Ryabukhin. The purpose of washing the samples was to remove oil and exogenous metal contamination.

After washing, the samples were dried at $40^{\circ} \mathrm{C}$ and weighed in the irradiation container. Hair zinc was determined without any chemical process by the $k_{0}$-instrumental neutron activation analysis ${ }^{15}$ at the Division for Reactor and Irradiation, Laboratory of Neutron Activation Analysis, Development Center for Nuclear Technology/ Brazilian Commission for Nuclear Energy (Centro de Desenvolvimento da Tecnologia Nuclearl Comissão Nacional de Energia Nuclear CDTN/ (NEN), using the TRIGA MARK I IPR-R1 nuclear reactor, based on the method described by 
Menezes et al. ${ }^{14}$ Stunting was associated with hair zinc levels below $70 \mu \mathrm{g}$ of zinc per gram of hair ${ }^{16}$.

\section{Statistical analyses}

The distribution of each variable was tested for normality before analysis, using the Kolmogorov-Smirnov goodness-of-fit test. Where necessary, data were normalized using the appropriate transformations. Data are presented as means, medians and standard deviations. The Kruskal Wallis test was used to examine the association between plasma zinc, hair zinc and gender. Weight-for-age (WAZ), height-for-age (HAZ) and weight-for-height ( $\mathrm{WHZ}$ ) Z-scores were calculated by using the WHO's reference curves ${ }^{8}$ and the Epi Info software, version 6 (Centers for Disease Control, Atlanta, GA). Correlations, student's t-test, analyses of variance and the Neuman-Keuls multiple range test were used as appropriate. Statistical analyses were performed by the SPSS software (version 10.0; SPSS Inc., (hicago). The acceptable level of statistical significance for all tests was $p<0.05$. Results are expressed as arithmetic means (Standard Deviation-SD) and ranges.

\section{RE S U LT S}

Based on the 2000 Brazilian Census 6 , $62.2 \%$ (28) of the children from São João da Chapada, $85.7 \%$ (6) of the children from Sopa, $40.6 \%$ (13) of the children from Conselheiro Mata, $34.5 \%$ (30) of the children from Desembargador Otoni, $87.5 \%$ (24) of the children from Planalto de Minas, $74.4 \%$ (29) of the children from Senador
Mourão, $47.1 \%$ (8) of the children from Mendanha and $39.8 \%$ (24) of the children from Inhai participated in the study, totaling 176 children. Therefore, the children who participated represented more than half $(56.4 \%)$ of the estimated 312 children registered in the last census.

The mother's or guardian's baseline socioeconomic indicators had no statistically significant associations with the biological variables. The outstanding features were that: 1) most of the children belonged to families of low socioeconomic status, as indicated by the mother's or guardian's low education level and income. Approximately $80.8 \%$ (80) of the 99 mothers had an income $\leq R \$ 300$ reais (US\$128) per month, which was equal to the Brazilian average for the same year ${ }^{6}$; 2) $50.5 \%$ (60) of the mothers responded that they had finished elementary school; 3) $70 \%$ (72) of the family members did not sleep alone in the bed; and 4) $14 \%$ (15) and $8 \%$ (9) of the mothers indicated that electricity was either shared with a neighbor or there was no electricity, respectively. The mean age of the children was 15.8 (SD=6.2) months, of which 91

Table 1. Characteristics of children from a rural region of Northeast Minas Gerais, Brazil, 2006.

\begin{tabular}{lrc}
\hline Variable & M & SD \\
\hline Age, mo $(\mathrm{n}=176)$ & 15.80 & 6.2 \\
Weight, kg & 9.94 & 1.9 \\
Height, cm & 78.00 & 7.3 \\
WAZ & -0.45 & 1.3 \\
HAZ & -0.16 & 1.5 \\
WHZ & -0.37 & 1.1 \\
Plasma zinc, mol L-1 $(n=152)^{-125)}$ & 15.90 & 4.4 \\
Hair zinc, $\mathrm{gg} \mathrm{g}^{-1}(\mathrm{n}=125)$ & 135.80 & 00.6 \\
Girls, $\mathrm{n}$ & 91.00 & $(51.7 \%)$ \\
\hline
\end{tabular}

Table 2. Distribution of zinc levels in plasma zinc and hair zinc, according to gender in children from a rural region of Northeast Minas Gerais, Brazil, 2006.

\begin{tabular}{|c|c|c|c|c|c|c|}
\hline \multirow{2}{*}{ Gender* } & \multicolumn{3}{|c|}{ Plasma zinc, $\mu \mathrm{mol} \mathrm{L-1}$} & \multicolumn{3}{|c|}{ Hair zinc, $\mu \mathrm{g} \mathrm{g}^{-1}$} \\
\hline & $n$ & Mean & SD & $n$ & Mean & SD \\
\hline Male & 75 & 16.2 & 4.8 & 47 & 154.8 & 141.4 \\
\hline Female & 77 & 15.5 & 4.1 & 78 & 124.4 & 63.2 \\
\hline
\end{tabular}

* Nonsignificant differences $(p>0.05)$ for plasma zinc and hair zinc means between genders.

SD: standard deviation. 
(51.7\%) were girls. The mean plasma zinc and hair zinc levels of 152 and 125 children were 15.9 $(\mathrm{SD}=4.4) \mu \mathrm{mol} \mathrm{L} \mathrm{L}^{-1}$ and $135.8(\mathrm{SD}=100.6) \mathrm{\mu g} \mathrm{g}^{-1}$, respectively (Table 1). Zinc deficiency according to plasma zinc and hair zinc levels was found in $11.2 \%$ (17) and $16.8 \%$ (21) of the sample, respectively. Mean plasma zinc and hair zinc in boys and girls are shown in Table 2 . There were no significant differences in plasma zinc or hair zinc deficiencies between genders $(p>0.05)$. A total of 176 children had their CRP determined. According to the CRP test, only one child (0.01\%) was considered to have chronic disease (CRP $>10 \mathrm{mg} / \mathrm{L}$ ). The age group distribution of the children in relation to plasma zinc and hair zinc is shown in Table 3. Means for children aged $\leq 11$ (49) and >11 (127) months for plasma zinc and hair zinc were $15.4(\mathrm{SD}=4.2) \mu \mathrm{mol} \mathrm{L} \mathrm{L}^{-1}$ and 139.5 $(\mathrm{SD}=72.1) \mu \mathrm{g} \mathrm{g}^{-1}$ and $16.0(\mathrm{SD}=4.5) \mu \mathrm{mol} \mathrm{\textrm {L } ^ { - 1 }}$ and $134.3(S D=110.3) \quad \mu g \quad g^{-1}$, respectively. Anthropometric results showed that 8.0\% (14), $6.8 \%(12)$ and $3.4 \%(6)$ of the children were underweight (WAZ less than -2), stunted (HAZ less than -2) and wasted (WHZ less than -2) according to the Z-score values, respectively. On the other hand, $4.0 \%$ (7) of the subjects were overweight (WAZ greater than 2 Z-scores). There were no significant correlations among anthropometric measurements, Z-scores and plasma zinc and hair zinc levels $(p=0.41)$.

Mean zinc consumption was 3.6 ( $\mathrm{SD}=2.1$ ) $\mathrm{mg} / \mathrm{Zn}$ per day. Overall zinc consumption was greater than the EAR (Estimated Average Requirement) of $2.5 \mathrm{mg} / \mathrm{Zn}$ per day and RDA (Recommended Daily Allowance) of 3.0mg/Zn per day ${ }^{11}$. Nearly one-third (30.6\%) of the children consumed less zinc than the daily EAR. However, $19.4 \%$ (7) of the children were found to consume a quantity of zinc greater than the UL (Upper Limit). There was no significant difference when the ranking test was used to assess dietary zinc in relation to plasma zinc and hair zinc levels $(p>0.05)$ (Table 4).

\section{DISCUSSION}

The present study was conducted in a poor region in the northeast of the state of Minas Gerais, Brazil. To date, the true prevalence of zinc deficiency among children in Brazil is unknown because no national surveys have done biochemical assessments of zinc status.

The situation on micronutrient deficiencies in children is particularly scarce in terms of iron, zinc and vitamin A deficiencies. The little available data comes from regional studies conducted over the past twenty years in Brazil. Beinner et al. ${ }^{17}$ showed that anemia affects more than $40 \%$ of the child population studied in an underdeveloped

Table 3. Observed means of plasma zinc and hair zinc, according to age in children from a rural region of Northeast Minas Gerais, Brazil, 2006.*

\begin{tabular}{|c|c|c|c|c|c|}
\hline \multirow{2}{*}{ Age, $m$} & \multirow{2}{*}{$n$} & \multicolumn{2}{|c|}{ Plasma zinc $\left(\mu \mathrm{mol} \mathrm{L}{ }^{-1}\right)$} & \multicolumn{2}{|c|}{ Hair zinc $\left(\mu \mathrm{g} \mathrm{g}^{-1}\right)$} \\
\hline & & Mean & SD & Mean & SD \\
\hline$\leq 11$ & 49 & 15.4 & 4.2 & 139.5 & 72.1 \\
\hline$>11$ & 127 & 16.0 & 4.5 & 134.3 & 110.3 \\
\hline
\end{tabular}

*Values are means and SD: standard deviation; $n=176$ children.

Table 4. Dietary consumption, by quartiles, of zinc in relation to plasma zinc and hair zinc levels in children from a rural region of Northeast Minas Gerais, Brazil, 2006.

\begin{tabular}{|c|c|c|c|c|}
\hline \multirow{2}{*}{ Quartiles of dietary zinc consumption* } & \multicolumn{2}{|c|}{ Hair zinc $\left(\mu g^{-1}\right)$} & \multicolumn{2}{|c|}{ Plasma zinc $\left(\mu \mathrm{mol} \mathrm{L}{ }^{-1}\right)$} \\
\hline & Mean & SD & Mean & SD \\
\hline $1(2.5 \mathrm{mg})$ & 123.1 & 52.7 & 17.0 & 4.4 \\
\hline $2(2.7 \mathrm{mg})$ & 128.4 & 68.3 & 15.7 & 4.4 \\
\hline 3 (3.6mg) & 140.3 & 77.6 & 17.2 & 4.2 \\
\hline 4 (6.3mg) & 160.7 & 118.6 & 16.1 & 3.9 \\
\hline
\end{tabular}

*Nonsignificant differences between the measured values and quartiles (Kruskal Wallis).

SD: standard deviation; $n=96$ children. 
region in the northeast of the state of Minas Gerais. What is known from the few studies published regarding zinc deficiency in children is that a deficiency of this trace element exists in poor, at-risk populations $\boldsymbol{s}^{4,5,18}$.

In this study, the plasma zinc and hair zinc levels in children from all eight rural districts of Diamantina were determined. The percent of children with plasma zinc and hair zinc levels below the cut-off points for deficiency was $16.8 \%$ and $11.2 \%$, respectively. Fávaro et al. ${ }^{5}$, in the South of Brazil, reported a similar plasma zinc deficiency; $13 \%$ of the 126 children examined were shown to have inadequate plasma zinc concentrations, with zinc levels $<70 \mu \mathrm{g} \mathrm{g}^{-1}$. In an earlier study, Dórea et al. ${ }^{18}$, in Northeast Brazil, reported hair zinc levels $<70 \mu \mathrm{g} \mathrm{g}^{-1}$ in $15 \%$ (28) of the 115 children aged one to twelve years. There was no significant difference between genders regarding plasma zinc and hair zinc in this study. This is in agreement with Fávaro et al. ${ }^{5}$. However, studies that investigated hair zinc levels in children done by Sturaro et al. ${ }^{19}$, in Italy, and Zachwieja et al. ${ }^{20}$, in Poland, showed that young girls had significantly more zinc in hair than boys.

Caution should be exercised in relation to plasma zinc and hair zinc interpretations, as the former and latter reflect marginal stages of deficiency during different biological periods. Chronic zinc deficiency can be well assessed by determining hair zinc levels. On the other hand, plasma zinc levels will indicate current zinc stores in the bodies of healthy subjects ${ }^{21}$.

The C-reactive protein tests indicated that only one $(0.01 \%)$ of the children suffered from chronic infection. C-reactive protein, an acute phase protein, is synthesized by hepatocytes in response to infection. Its meaning in the diagnosis of acute infection and tissue destruction is well established ${ }^{22}$. Its levels will change according to disease activity. They start to increase 6 hours after the onset of infection and reach peak levels two days after the onset. Therefore, chronic infection was unlikely to have interfered with plasma zinc levels.
Hair zinc levels were assessed with the analytical technique $\mathrm{k}_{0}$-Instrumental Neutron Activation Analysis, which was suitable to determine zinc levels in hair samples. The zinc levels in the hair reference material $(180 \pm 10)$ $\mu \mathrm{g} \mathrm{g}^{-1}$ was in good agreement with the certified value, Human Hair GBW 09101 from the Shangai Institute of Nuclear Research, (189 \pm 8$) \mu \mathrm{g} \mathrm{g}{ }^{-1}$, validating the analysis.

Stunting was not associated with plasma zinc or hair zinc levels $<10 \mu \mathrm{mol} \mathrm{L}^{-1}$ or $<70 \mu \mathrm{g} \mathrm{g}^{-1}$, respectively. However, an earlier study done by Xue-Cun et al. ${ }^{23}$ in China, reported that plasma zinc levels were significantly correlated with anthropometric parameters and weight-for-height Z-score.

Dietary zinc consumption measured quantitatively in the child's food eaten over three non-consecutive days was considered inadequate for $30.6 \%$ (30) of the children, according to the cut-off for EAR for this element, which is $2.5 \mathrm{mg} /$ Zn per day for this age group ${ }^{11}$. This translates to roughly one third of the study sample, and is a close estimate of the inadequate consumption of high-zinc foods in the children's diet. On the other extreme, $19.4 \%$ (18) of the children exceeded the Tolerable Upper Intake Level (UL). More specifically, three children under 12 months of age exceeded the UL of $5 \mathrm{mg} / \mathrm{Zn}$ per day, and 15 children over 12 months of age exceeded the UL of $7 \mathrm{mg} / \mathrm{Zn}$ per day. Adverse effects of overconsumption of dietary zinc are rare.

The highest zinc source was cow's milk, which is high in zinc but the bioavailability is low ${ }^{24}$. It was also noted that food variety was of poor quality and diversity. For the most part, rice, beans and corn meal were the main foods prepared by the mother or guardian. Consumption of meat products, vegetables, legumes and fruits was small. Although breastfeeding is an excellent source of zinc, in terms of bioavailability, it was not commonly practiced. It is interesting to point out that as the consumption of dietary zinc increased, 
so did the mean quartile hair zinc concentrations; however, this increase was not significant (Table 4). Plasma zinc showed small, nonsignificant differences between mean quartile plasma zinc levels in relation to dietary zinc consumption (Table 4). This may be explained by the fact that the distribution of circulating plasma zinc is roughly 50 times lower than the concentration of zinc in tissues, such as muscle and liver, and this would not necessarily translate to a deficiency of this mineral ${ }^{25}$.

The results of this investigation suggest the need to better assess the problems of micronutrient deficiencies in children suffering from malnutrition. Our findings highlight the importance of practical low-cost strategies to increase the production and consumption of meat and poultry in rural areas like Diamantina to ensure adequate dietary intakes of readily available zinc by children. Options for nutritious variety of dietary intake could contribute towards enriching the quality of foods consumed by this population without necessarily costing the household more given nutritional counseling is available in socioeconomically deprived communities. Furthermore, education to increase awareness of the benefits of exclusive breastfeeding during the first six months of a child's life will greatly contribute to the prevention of infant malnutrition and of sequelae that may appear in later years.

\section{ACKNOWLEDGEMENTS}

The authors wish to thank Juliana Mambrini and Jorge Gustavo V. Melendez, for the statistical analysis; Fernanda Vasconcelos, Nadja Maria Murta, for the technical assistance in the dietary assessment. Finally, we give special thanks to the mothers, guardians and children for participating in this research.

\section{COLLABORATORS}

M.A. BEINNER was the research project leader. M.A.B.C. MENEZES was responsible for the laboratory analysis of hair zinc. J.B.B. SILVA was responsible for the laboratory analysis of plasma zinc. F.R. AMORIM was responsible for field data collection. A.K. JANSEN was responsible for the nutritional analysis. J.A. LAMOUNIER, physician, was responsible for the physical examinations.

\section{REFERE N CE S}

1. Beinner MA, Lamounier JA. Recent experience with fortification of foods and beverages with iron for the control of iron-deficiency anemia in Brazilian children. Food Nutr Bul. 2003; 24(3):268-74.

2. Hallberg $L$, Brune $M$, Rossander L. Iron absorption in man: ascorbic acid and dose-dependent inhibition by phytate. Am J Clin Nutr. 1989; 49(1): 140-4.

3. Bhatnagar S, Natchu UC. Zinc in child health and disease. Indian J Pediatr. 2004; 71(11):991-5. doi:10.1007/BF02828114.

4. Silva APR, Vitolo MR, Zara LF, Castro CFS. Effects of zinc supplementation on 1 to 5 year old children. J Pediatr. 2006; 82(3):227-31. doi:10.2223/JPED. 1480.

5. Fávaro RMD, Vannucchi $H$. Plasma zinc levels and the anthropometry of children on the outskirts of the urban center, Brazil. Rev Saúde Pública. 2004; 24(1):5-10.

6. Instituto Brasileiro de Geografia e Estatística. Censo demográfico de 2003: característica da população. Rio de Janeiro: IBGE; 2003.

7. World Health Organization. Nutritional anemias. Geneva: WHO; 1968. Technical Report Series, 405.

8. World Health Organization. Child growth standards: length/height-for-age, weight-for-age, weight-for-length, weight-for-height and body mass index-for-age: methodos for development. 2006 [cited 2007 Feb 1]. Available from: <http:// www.who.int/childgrowth/standards/technical report.pdf>.

9. Tabela Brasileira de Composição de Alimentos. Campinas: Unicamp; 2006.

10. Philippi ST. Tabela de composição de alimentos: suporte para decisão nutricional. São Paulo: Coronaio; 2002.

11. Otten JJ, Hellig JP, Meyers LD, Editors. Dietary reference intakes: the essential guide to nutrient requirements. Washington (DC): National Academies Press; 2006.

12. López de Romaña G, Cusirramos S, López de Romaña D, Gross R. Efficacy of multiple 
micronutrient supplementation for improving anemia, micronutrient status, growth, and morbidity of Peruvian infants. J Nutr. 2005; 135(3): 646S-52S.

13. Kongsbak K, Wahed MA, Friis H, Thilsted SH. Acute phase protein levels, T. trichiura, and maternal education are predictors of serum zinc in a crosssectional study in Bangladeshi children. J Nutr. 2006; 136(8):2262-8.

14. Menezes MABC, Maia ECP, Albinati CCB, Sabino CVS, Batista JR. How suitable are scalp hair toenail as biomonitors? J Radioanal Nucl Chem. 2004; 259(1):81-6. doi:10.1023/B:JRNC.000001581 0.22775 .72

15. Menezes MABC, Schayer SCV, Franco MB, Kastner GF, Montoya Rossi EH. Ko - Instrumental Neutron Activation establishment at CDTN, Brazil: a successful story. J Radioanal Nucl Chem. 2003; 257(3):627. doi:10.1023/A:1026104613854.

16. Hambidge KM, Hambidge C, Jacobs M, Baum JD. Low levels zinc in hair, anorexia, poor growth, and hypogesia in children. Pediatr Rev. 1972; 6(12): 868. doi:10.1203/00006450-197212000-00003.

17. Beinner MA, Lamounier JA, Tomaz T. Effect of ironfortified drinking water of daycare facilities on the hemoglobin status of young children. J Am Coll Nutr. 2005; 24(2):107-14.

18. Dórea JG, Horner MR, Bezerra VL, Pereira MG, Salomon JB. Hair zinc levels and nutritional status in urban children from Ilhéus, Bahia, Brazil. Hum Nutr Appl Nutr. 1982; 36A(1):63-7.

19. Sturaro A, Parvoi G, Doretti L, Allegri G, Costa C. The importance of color, age and sex on the content of zinc, copper, nickel, manganese, and lead in human hair. Biol Trace Elem Res. 1994; 40(1):1-8.

20. Zachwieja Z, Chlopicka J, Schlegel-Zawadzka M, Zagrodzki P, Wypchlo J, Krosniak M. Evaluation of zinc content in children's hair. Biol Trace Elem Res. 1995; 47(1-3):141-5. doi: 10.1007/BF02790111.

21. Silva-Santana SC, Diniz AS, Lola MMF, Oliveira RS, Silva SMM, Oliveira SF, et al. Parameters of evaluation of zinc nutritional status: comparison between zinc hair rates and serum alkaline phosphatase in pre-scholars of the Municipality of João Pessoa, Paraíba. Rev Bras Saúde Matern Infant. 2002; 2(3):275-82. doi:10.1590/\$1519-38 292002000300008.

22. Peltola V, Mertsola J, Ruuskanen O. Comparison of total white blood cell count and serum C-reactive protein levels in confirmed bacterial and viral infections. J Pediatr. 2006; 149(5):721-4. doi: 10.10 16/j.jpeds.2006.08.051.

23. Chen XC, Yin TA, He JS, MA QY, Han ZM, Li LX. Low levels of zinc in hair and blood, pica, anorexia, and poor growth in Chinese preschool children. Am J Clin Nutr. 1985; 42(4):694-700.

24. Pabon ML, Lonnerdal B. Bioavailability of zinc and its binding to casein in milks and formulas. J Trace Elem Biol. 2000; 14(3):146-53. doi:10.1016/S09 46-672X(00)80003-6.

25. Brown $\mathrm{KH}$. Effect of infections on plasma zinc concentration and implications for zinc status assessment in low-income countries. Am J Clin Nutr. 1998; 68(Suppl):425S-9S.

Received on: 7/3/2008

Final version resubmitted on: 2/3/2009

Approved on: 22/4/2009 
